\title{
Reflections on the Accounting Treatment of Lessees in the New Lease Standard Methods and Examples Based on New Lease Standards 21
}

\author{
Yingting Liu ${ }^{1, *}$ \\ ${ }^{1}$ School of Accountancy, Xinhua College of Sun Yet-sen University, Guangzhou, Guangdong 510000, China \\ *Corresponding author. Email: 382713919@qq.com
}

\begin{abstract}
The new lease standard no longer makes distinguishes between operating leases and financial leases for accounting treatment of lessees, and uniformly uses the "right-of-use model" to separately list an asset and a liability in the balance sheet. The accounting treatment has undergone a disruptive change in comparison with the past. This article intends to analyze the lessees' accounting requirements from the original lease standard and the new lease standard, and proposes problems, reflections and suggestions for lessee accounting treatment after implementing the new standard.
\end{abstract}

Keywords: new lease standard, lessee, accounting treatment

\section{INTRODUCTION}

A large number of leased assets around the world are undervalued, and financial information is extremely lacking in comparability. Investors and analysts often adjust their statements based on the disclosure information of off-balance sheet leases of enterprises in order to obtain true information about the company. However, most investors and analysts cannot adjust the statements accurately, which leads to a decrease in the comparability of the financial statements. The application of the right-of-use asset model reflects the financial status of the leased enterprise more accurately and effectively, and is also very beneficial to investors' decisions. On December 7, 2018, the Ministry of Finance issued the 2018 "New Lease Standards" (CAS 21), and subsequently, the Ministry of Finance issued the 2019 "Lease Guideline". The guideline laid the foundation for the implementation of the new standard through numerous detailed guidelines and examples. CAS 21 was formulated by China in the light of international lease criterion and combined with China's actual conditions. According to the main content and characteristics of IFRS16 officially released in January 2016, the main impacts and responses of IFRS16 are explained (Lu Qilin, 2017). It proposes the revised changes of the new international standards, and analyzes the impact since the promulgation and implementation, and proposes China's countermeasures

*Project: Guangdong Province Education and Research "Thirteenth Five-Year Plan" 2018 Annual Project (Project No.: 2018GXJK261) and Reform of the Internet + blended Teaching Model in Xinhua College of Sun Yat-sen University in 2018 (Project No.: 2018HHJG007)
(Zhou Long, Li Yaxing, 2016). Based on the literature on the issue of international leasing standards in recent years, this article is based on the 2018 "New Lease Standards" issued by the Ministry of Finance on December 7, 2018. By comparing and analyzing the accounting treatment of the new lease standard by the lessee, it is hoped to provide a reference for the effective application of the new lease standard in practice.

\section{A. Specific requirements for the implementation of the new lease standard}

The new lease standard has made major changes to the lessee's accounting treatment, lease definition, consolidation, etc., and has more specific and detailed disclosure of the lessor's accounting information, and users of the report can also obtain more useful information from it. The time when the Chinese and foreign listed companies implement the new leasing standards is different: the implementation time of overseas listed companies or Chinese and foreign simultaneous listed companies is January 1, 2019; the implementation time of other companies that implement corporate accounting standards is January 1, 2021; Enterprises whose subsidiary's overseas listing or parent company's overseas listing are prepared in accordance with international standards or corporate accounting standards can implement the new lease standard in advance, but the implementation time must be later than the date of the new "Financial Instruments Recognition and Measurement" standard and the new "Revenue" standard. How to implement and respond to the new leasing standards is an important issue that 
needs to be solved at present. The specific implementation time is shown in "Table I".

TABLE I. IMPLEMENTATION TIME OF NEW LEASE STANDARDS AND RELATED REGULATIONS

\begin{tabular}{|c|c|c|}
\hline Adapted company & Implementation time & Regulations \\
\hline $\begin{array}{l}\text { Overseas listed companies or Chinese and overseas } \\
\text { listed companies }\end{array}$ & January 1,2019 & \multirow{3}{*}{$\begin{array}{l}\text { The retrospective adjustment } \\
\text { method is adopted, and the } \\
\text { cumulative impacts are adjusted } \\
\text { for retained earnings at the } \\
\text { beginning of the year. } \\
\text { Information for comparable } \\
\text { periods doesn't need to adjust. }\end{array}$} \\
\hline $\begin{array}{lcc}\text { Other companies } & \text { implementing } & \text { corporate } \\
\text { accounting standards } & & \\
\end{array}$ & January 1, 2021 & \\
\hline $\begin{array}{l}\text { Enterprises whose subsidiary's overseas listing or } \\
\text { parent company's overseas listing are prepared in } \\
\text { accordance with international standards or corporate } \\
\text { accounting standards may implement the new lease } \\
\text { standard in advance. }\end{array}$ & $\begin{array}{l}\text { Later than the date of the new } \\
\text { "Financial Instruments Recognition } \\
\text { and Measurement" standard and the } \\
\text { new "Revenue" standard. }\end{array}$ & \\
\hline
\end{tabular}

a. Source: December 7, 2018, Ministry of Finance issued "Accounting Standards for Business Enterprises No. 21 — Leasing".

\section{NEW AND OLD LEASE STANDARDS RELATED TO LESSEE ACCOUNTING TREATMENT}

\section{A. Analysis of standard provisions}

The original lease standard divided lease types into financing leases and operating leases. Under the financial lease method, the lessee will list the assets obtained from the financial lease as one asset and one liability in the balance sheet. Under the operating lease method, the lessee recognizes the lease fee paid as an expense, which is listed in the income statement, and the assets obtained from the lease are not recognized, resulting in an incomplete reflection of operating lease assets in the balance sheet, and the comparability of financial statements has also decreased.

The new lease standard no longer distinguishes leases into operating leases and financial leases, but instead recognizes them as a "right-of-use asset" and "lease liability", and depreciates the right-of-use asset in accordance with the fixed asset standard. In addition, the disclosure of the lessor's accounting information is more abundant, providing more useful accounting information.

\section{B. Analysis of similarities and differences of the new and old standards for the lessee's accounting treatment}

The original lease standard and the new lease standard have the same accounting treatment for lessees: the accounting treatments for financial lease lessees are basically the same. On the lease start date, the lessee recognizes the assets of the financial lease as a leased asset and related liabilities. The subsequent measurement model of the leased assets is the cost model. Depreciation of the leased assets is based on the fixed asset standard. At the same time, the leased assets are tested for impairment in accordance with the asset impairment standards, impairment losses are recognized, financial lease assets are listed in the balance sheet.
The differences between the original lease standard and the new lease standard for the lessee's accounting are: The original lease standard did not recognize an asset and a liability for assets leased under operating leases, and did not list it in the balance sheet. It only recognized lease expenses separately and disclosed information related to operating leases in the notes; The new lease standard no longer distinguishes between operating leases and financial leases for lessees. The lessee's accounting treatment of operating lease assets has been changed from a dual model to a single model, that is, the lessee recognizes an asset and related liabilities for the assets leased from the operating lease on the lease start date, uses the cost model to measure it in the subsequent measurement process, and depreciates the right-of-use asset in accordance with the fixed asset standards, while considering the lease and interest expenses incurred during the use process. According to the provisions of the asset impairment standards, the right-of-use assets are tested for impairment, and the impairment of assets that have been impaired is provided for losses.

\section{LESSEE'S ACCOUNTING TREATMENT}

The original lease standard only reflected the accounting information of the operating lease lessees off-balance sheet, and did not explicitly regulate the processing of contract changes after the lease and the revaluation of options. The handling of this in practice was not uniform and was controversial. The new standard requires the cost model to be used for subsequent measurement of right-of-use assets, to determine whether the right-of-use assets are impaired, and to depreciate and accrue expenses separately. The new lease standards clearly stipulate that the lessee should re-evaluate whether to purchase the right-of-use assets at maturity, whether to renew the lease at maturity, or to terminate the lease at maturity, and make corresponding accounting treatments. In addition, lease changes should be re-recognized as a lease liability or reflected separately as a lease. The subsequent measurement of the lessee is more complete in the new lease standard, and the accounting information 
disclosure of the lessor and lessee is also more abundant and reliable. Based on the requirements and practices of the new lease standard, the author conducted a brief analysis.

\section{A. Initial confirmation of the lessee}

The new standard no longer distinguishes between operating leases and financial leases for lessees, and there is no need to judge the type of lease when accounting for lease operations. The lessee recognizes an asset and a related liability at the beginning of the lease. The specific accounting treatment is shown in "Table II".

TABLE II. INITIAL CONFIRMATION OF THE LESSEE

\begin{tabular}{|c|c|c|}
\hline Initial measurement & Processing principle & Accounting treatment \\
\hline $\begin{array}{l}\text { Initial measurement of lease } \\
\text { liabilities }\end{array}$ & $\begin{array}{l}\text { It uses the leased interest rate or incremental borrowing } \\
\text { interest rate as the discount rate to calculate the present } \\
\text { value of lease payments, and confirms the initial amount of } \\
\text { a "leasing liability" }\end{array}$ & \multirow{2}{*}{$\begin{array}{l}\text { Borrow: Right-of-use assets } \\
\text { Lease liabilities - unrecognized } \\
\text { financing costs } \\
\text { Loan: Lease liabilities - lease payment } \\
\text { Bank deposit (initial direct costs) } \\
\text { Estimated liabilities - recovery } \\
\text { costs }\end{array}$} \\
\hline $\begin{array}{l}\text { Initial measurement of right-of-use } \\
\text { assets }\end{array}$ & $\begin{array}{l}\text { "Right-of-use asset" initial cost }=\text { initial measurement } \\
\text { amount of lease liabilities - lease incentive }+ \text { initial direct } \\
\text { costs + recovery costs }\end{array}$ & \\
\hline
\end{tabular}

For example: A business enterprise is a general taxpayer. A real estate company signed a lease contract with the business enterprise on December 31, 2018. The contract stipulates the following relevant content: The lease will begin on December 31, 2018. One house (self-developed old project), the lease period is 5 years (starting and ending dates: December 31, 2018December 31, 2023). On December 31, 2019, 2020, 2021, 2022, and 2023, the rent will be paid 500,000 yuan (excluding tax), a total of 2.5 million yuan (excluding tax) (Simple tax calculation for developed old projects, VAT rate of 5\%). Assuming that the fair value of the house on December 31, 2019 is 1.68 million excluding tax and the interest rate stipulated in the house lease contract is 6\% (annual interest rate), after the contract expires on December 31, 2023, the lessee will return the property to the lessor after paying the rent as agreed. Assumptions: The unrecognized financing expenses to be apportioned in the current period are recognized according to the actual interest rate method; the lease period of the house is 5 years, and the depreciation method of the right-of-use asset is the average life method; the transaction fee and transportation expenses paid by the commerce and trade enterprise during the signing of the contract shall be 10,000 yuan (no input tax deductible); at the end of the lease period, the business enterprise needs to restore the original appearance of the leased house. A business enterprise estimates that it will cost 20,000 yuan to restore the house after the five-year lease expires.

According to the analysis of the above data, the initial measurement amount of the lease liability $=50 \times$ $4.2124=210.62$ (4.2124 is the annuity present value coefficient with interest rate of $6 \%$ and the period of 5 years)

Borrow: Right-of-use assets 213.62 39.38

Lease liabilities - unrecognized financing costs

Loan: Lease liabilities - lease payments 250

Bank deposit (initial direct cost) 1

Estimated liabilities - recovery costs 2

\section{B. Subsequent measurement of the lessee}

The lessee's subsequent measurement adopts the cost model, and the depreciation and impairment test of the right-of-use asset are based on the fixed asset standard and the asset impairment standard, respectively. In addition, the lessee calculates the interest expenses that should be borne by each period of the lease based on a certain interest rate, which are included in the current profit and loss or related asset costs as required. The variable lease payment is not included in the lease liability in the new lease standard, but is included in the current profit and loss when it actually occurs. The specific accounting treatment is shown in "Table III". 
TABLE III. SUBSEQUENT MEASUREMENT OF THE LESSEE

\begin{tabular}{|l|l|l|}
\hline \multicolumn{1}{|c|}{$\begin{array}{c}\text { Subsequent } \\
\text { measurement }\end{array}$} & \multicolumn{1}{|c|}{ Processing principle } & \multicolumn{1}{|c|}{ Accounting treatment } \\
\hline $\begin{array}{l}\text { Paying the lease } \\
\text { payment }\end{array}$ & $\begin{array}{l}\text { Lease liabilities decrease when lessee pays lease } \\
\text { payments }\end{array}$ & $\begin{array}{l}\text { Borrow: Lease liabilities - lease payments } \\
\text { Taxes payable - VAT payable (input tax) } \\
\text { Loan: Bank deposit }\end{array}$ \\
\hline $\begin{array}{l}\text { Recognition of } \\
\text { interest expenses }\end{array}$ & $\begin{array}{l}\text { The lessee calculates the interest expenses that should } \\
\text { be borne by each lease period based on a certain } \\
\text { interest rate, and includes them in the current profit or } \\
\text { loss or capitalization as required }\end{array}$ & $\begin{array}{l}\text { Borrowing: Financial costs / construction in progress, } \\
\text { etc. } \\
\text { Loan: Lease liabilities - unrecognized financing } \\
\text { expenses }\end{array}$ \\
\hline $\begin{array}{l}\text { Depreciation of } \\
\text { leased assets }\end{array}$ & $\begin{array}{l}\text { Depreciate the right-of-use assets with reference to } \\
\text { fixed asset standards (The right-of-use asset is usually } \\
\text { accrued from the month beginning the lease period. If } \\
\text { it is difficult to accrue, depreciation may also be } \\
\text { accrued from next month and disclosed in the notes) }\end{array}$ & $\begin{array}{l}\text { Boan: Accumulated depreciation of right-of-use } \\
\text { assets }\end{array}$ \\
\hline $\begin{array}{l}\text { Impairment of } \\
\text { leased assets }\end{array}$ & $\begin{array}{l}\text { Perform impairment test on the right-of-use asset with } \\
\text { reference to the asset impairment standard and } \\
\text { perform corresponding accounting treatment }\end{array}$ & $\begin{array}{l}\text { Borrow: Asset impairment losses } \\
\text { Loan: Provision for impairment of right-of-use assets }\end{array}$ \\
\hline $\begin{array}{l}\text { Variable lease } \\
\text { payments }\end{array}$ & $\begin{array}{l}\text { The variable lease payments that are not included in } \\
\text { the measurement of lease liabilities shall be included } \\
\text { in the current profit and loss when they actually occur. }\end{array}$ & $\begin{array}{l}\text { Borrow: Management expenses, etc. } \\
\text { Loan: Bank deposit }\end{array}$ \\
\hline
\end{tabular}

For example, following the example above, on December 31, 2019, the business enterprise paid the rent of 525,000 yuan (including tax) for the current year; the leased assets are depreciated on a straight-line basis, and the depreciation period is 5 years. The rightof-use asset is usually accrued from the month of the lease period, and the business enterprise is depreciated over 5 years, with an annual depreciation amount $=$ $213.62 \div 5=422,724$ yuan. The allocation of unrecognized financing costs is shown in "Table IV" below.

TABLE IV. UNRECOGNIZED FINANCING COST ALLOCATION

\begin{tabular}{|l|l|l|l|l|}
\hline $\begin{array}{c}\text { Serial } \\
\text { number }\end{array}$ & Year & $\begin{array}{c}\text { Lease } \\
\text { payments }\end{array}$ & Interest & Principal \\
\hline 0 & & & & 210.62 \\
\hline 1 & 2019 & 50 & 12.64 & 173.26 \\
\hline 2 & 2020 & 50 & 10.40 & 133.66 \\
\hline 3 & 2021 & 50 & 8.02 & 91.68 \\
\hline 4 & 2022 & 50 & 5.5 & 47.18 \\
\hline 5 & 2023 & 50 & 2.82 & 0.00 \\
\hline Footing & & 250 & 39.38 & \\
\hline
\end{tabular}

Calculating current interest on December 31, 2019

\section{Borrow: Finance expenses 12.64}

Loan: Lease liabilities — unrecognized financing expenses 12.64 2019

Depreciation charges accrued on December 31,

Borrow: Selling expenses 42.724

Loan: Accumulated depreciation of right-of-use assets 42.724
Note: The leased house is used daily by commercial enterprises and does not meet the capitalization requirements.

Paying rent on December 31, 2019

Borrow: Lease liabilities - lease payments 50

Taxes payable — VAT payable (input tax) 2.5

Loan: Bank deposit 52.5

It can assume that the fair value of this right-of-use asset as of December 31, 2019 is 1.68 million (excluding tax).

Book value of the right-of-use asset as of December $31,2019=213.62-42.724=170.896$ million yuan

The recoverable amount of the right-of-use asset as of December 31, $2019=1.68$ million yuan

Impairment number $=170.896-168=28.96$ million yuan

Borrow: Asset impairment loss 2.896

Loan: Provision for impairment of right-of-use assets 2.896

After the right-of-use asset is accrued for impairment, it cannot be reversed. The lessee makes subsequent depreciation based on the book value of the right-of-use asset after depreciation. Therefore, the annual depreciation amount from 2020 to $2023=$ $(213.62-42.724-2.986) \div 4=420,000$ yuan

\section{Confirmation of lease termination}

When the lease is terminated, the lessee should reevaluate: whether to purchase the right-of-use assets at maturity, whether to renew the lease at maturity, or to 
TABLE V. CONFIRMATION OF LEASE TERMINATION

\begin{tabular}{|l|l|l|}
\hline \multicolumn{1}{|c|}{ Lease termination } & \multicolumn{1}{|c|}{ Processing principle } & \multicolumn{1}{c|}{ Accounting treatment } \\
\hline $\begin{array}{l}\text { Enterprise sublease use right } \\
\text { assets to form a financial } \\
\text { lease }\end{array}$ & $\begin{array}{l}\text { The financial lease receivables are included in the } \\
\text { "financial receivables receivable". At the same } \\
\text { time, the book value of the originally recognized } \\
\text { right-of-use asset is derecognized, and the asset } \\
\text { disposal gain or loss or retirement gain or loss is } \\
\text { recognized. }\end{array}$ & $\begin{array}{l}\text { Borrow: Receivables from finance leases } \\
\text { Right-of-use asset impairment reserve } \\
\text { Accumulated depreciation of right-of-use assets } \\
\text { Loan: Right-of-use assets } \\
\text { Borrow or loan: Gains and losses on asset disposal } \\
\text { (banlance) }\end{array}$ \\
\hline $\begin{array}{l}\text { Business sublease use right } \\
\text { assets to form operating } \\
\text { leases }\end{array}$ & $\begin{array}{l}\text { It is included in "other receivables" based on } \\
\text { operating lease receivables. Meanwhile, the book } \\
\text { value of the originally recognized right-of-use } \\
\text { asset is derecognized, and the asset disposal gain } \\
\text { or loss or retirement gain or loss is recognized. }\end{array}$ & $\begin{array}{l}\text { Borrow: Other receivables } \\
\text { Right-of-use asset impairment reserve } \\
\text { Accumulated depreciation of right-of-use assets } \\
\text { Borrow or loan: Gains and losses on asset disposal } \\
\text { (banlance) }\end{array}$ \\
\hline $\begin{array}{l}\text { When the contract expires, } \\
\text { the lessee exercises the } \\
\text { purchase option and acquires } \\
\text { the ownership of the leased } \\
\text { asset }\end{array}$ & $\begin{array}{l}\text { When the contract expires, the payment option is } \\
\text { exercised. The sum of the book value of the } \\
\text { originally recognized right-of-use asset and the } \\
\text { paid purchase option is included in "fixed assets". }\end{array}$ & $\begin{array}{l}\text { Borrow: fixed assets } \\
\text { Accumulated depreciation of right-of-use assets } \\
\text { Loan: Right-of-use assets } \\
\text { Bank deposit }\end{array}$ \\
\hline $\begin{array}{l}\text { When the contract expires, } \\
\text { the lessee does not exercise } \\
\text { the purchase option and } \\
\text { terminates the lease }\end{array}$ & $\begin{array}{l}\text { Derecognize the book value of the "right-of-use } \\
\text { asset" }\end{array}$ & $\begin{array}{l}\text { Borrow: Provision for impairment of right-of-use assets } \\
\text { Accumulated depreciation of right-of-use assets } \\
\text { Loan: Right-of-use assets }\end{array}$ \\
\hline
\end{tabular}

For example, following the example above, after the contract expires on December 31, 2023, the lessee pays the rent in accordance with the contract and the house ownership is returned to the lessor real estate company.

Paying rent on December 31, 2023

Borrowings: Lease liabilities — lease payments 50

$\operatorname{tax}) 2.5$

Taxes payable - VAT payable (input

\section{Loan: Bank deposit 52.5}

Interest expense for the last year recognized on December 31, 2023

\section{Borrow: Finance expenses 2.82}

Loan: Lease liabilities — unrecognized financing expenses 2082

Book value of the right-of-use asset as of December 31,2023

Borrow: Provision for impairment of right-of-use assets 2.896 assets 210.724

Accumulated depreciation of right-of-use

Loan: Right-of-use assets 213.62

\section{Disclosure of lessee information}

The new lease standard clearly stipulates that the lessee should separately list an asset and a liability on the balance sheet. Lease liabilities are classified into long-term liabilities and long-term liabilities due within one year according to their nature, and right-of-use assets are classified into long-term assets and long-term assets due within one year according to their nature. The depreciation expense of the right-of-use asset and the interest on the lease liability are shown separately in the income statement. Paying the principal and interest of the lease liability in cash should be included in the cash flow statement of financing activities. The lease fees and variable lease payments for short-term leases and leases of low-value assets are cash outflows from operating activities. The information disclosure requirements of the new lease standards fully reflect the company's assets and liabilities, eliminate the opportunity for lessees to use operating leases for offbalance sheet financing, and improve the transparency and comparability of statements.

\section{REFLECTIONS AND SUGGESTIONS ON THE NEW LEASE STANDARDS FOR THE ACCOUNTING TREATMENT OF LESSEES}

First, under the new leasing standards, the lease of investment real estate is not explicitly excluded from the scope of the lease standards. The new lease standard requires the subsequent measurement of leased assets to use the cost model. The author believes that the new lease standard applies to investment real estate leasing. If the lessee uses the fair value measurement model to measure investment real estate, the right-of-use assets that meet the definition of investment real estate can also be carried out using the fair value measurement model.

Second, under the new lease standard, there are special provisions for subleasing, that is, "the subleasor 
should be based on the right-of-use asset generated by the original lease, not the underlying asset of the original lease". According to the standards, the new lease standard no longer distinguishes the types of leases of lessees and adopts the right-of-use asset model uniformly. Therefore, the accounting treatment of subleases should also be based on the right-of-use assets recognized in the original lease. If the sub-lease is a finance lease, the original right-of-use asset should be derecognized and the profit or loss should be confirmed; if the sub-lease is an operating lease, the right-of-use asset should be reasonably depreciated during the sub-lease period, matching the rental income. At this time, the right-of-use asset for the same leasehold property will appear in the statements of the sub-lessor and lessee at the same time. The author believes that the reason for this situation is that the changes to the new standard are only for lessees, and for the lessors, it still needs to make distinguish between financial leases and operating leases.

Third, the impairment provisions for the right-ofuse assets in the new lease standard refer to the provisions of "Enterprise Accounting Standards No. 8 - Asset Impairment", and it needs to use similar methods to fixed assets to determine whether there are signs of impairment. In many cases, the right-of-use asset cannot generate cash inflow independently, especially if the leased asset is used for its own production and operation rather than sublease. The author believes that if the leased assets are merged into the asset group to which they belong, considering the signs of impairment and impairment testing as a whole, they can better reflect the effectiveness of the assets.

Forth, the new standard includes the lease fee paid in each period as the initial value of the right-of-use asset. In the case of variable lease costs, the new standard simplifies the treatment and does not include the initial value of the right-of-use asset. Similarly, as it in the original standard, it is included in the current lease expenses. This requirement caused the same nature of expenses to be artificially shown in the balance sheet and income statement. If most of the future price of a lease contract is variable, then the initial asset value only contains a small part of the total price in the contract, can it reasonably reflect the value of this lease behavior? Does the new lease standard work as it should? These issues need to be continuously improved by the new standard.

\section{v. CONCluSion}

To sum up, the author briefly analyzes the accounting treatment of the lessee by the new lease standard, expounds the changes in the accounting confirmation and measurement of the lessee by the new lease standard, and analyzes the impact of changes in the new lease standards on the lessee's accounting confirmation and measurement through specific cases. Because the new lease standards were not promulgated for a long time, and Chinese listed companies have not yet implemented the new standards, the author's interpretation of the relevant provisions of the new lease standard and its application guide needs to be continuously improved. It is hoped that this article will help learners to deepen their understanding of the new lease standard and provide valuable reference for practitioners.

\section{References}

[1] The Ministry of Finance, "Accounting Standards for Business Enterprises No. 21-Leasing", December 7, 2018. (in Chinese)

[2] 'Enterprise Accounting Standards No. 21-Leasing' Application Guide 2019. (in Chinese)

[3] Yu Yingmin, Wang Zifan, The Impact of IFRS \& CAS's New Leasing Standards on Corporate Finance and Countermeasures [J]. Frends of Accountings, 2019 (12): 133-135. (in Chinese)

[4] Xu Jingchang, Liu Chang, An Analysis of the Amendments to the Leasing Standards and Their Impact [J]. Finance and Accounting Monthly, 2019 (03): 57-61. (in Chinese)

[5] Huang Yijian, An Analysis of the Application of New International Leasing Accounting Standards: A Case Study of China Ocean Shipping Holdings Co., Ltd. [J]. 2018 (16): 119 121. (in Chinese)

[6] Responsible person in charge of the Accounting Department of the Ministry of Finance answers reporters' questions on the issuance and implementation of the new lease standards [J]. Finance \& Accounting, 2019 (01): 4-5. (in Chinese)

[7] Relevant person in charge of the Accounting Department of the Chinese Accounting Association and the Ministry of Finance answered questions from reporters on the release and implementation of the new lease standards. (in Chinese) 